VISION: Journal of Indian Taxation Volume 4, Issue 2, Jul-Dec 2017, pp. 82-101 doi: $10.17492 /$ vision.v4i02.11780

\title{
Fiscal Consolidation and Macroeconomic Variables in India: A Cointegration Analysis
}

\author{
Chittaranjan Nayak* and Manaswini Panda**
}

\begin{abstract}
Fiscal consolidation is in the forefront of policy discussion in India since 1990s. But the debate on fiscal consolidation and its real effects has been unable to attain any culmination so far on analytical as well as empirical grounds. The present paper tries to examine the impact of fiscal consolidation on growth, inflation, private investment, and exchange rate in India by analysing a time series data for the period from 1980-81 to 2013-14. The paper observes that there exists a long run relationship between GDP, fiscal consolidation, inflation and private investment. Fiscal deficit reduces GDP significantly. This finding gives empirical support to the neoclassical school of thought. However, the paper does not find any significant crowding-out evidence in India. The conclusion as such is sensitive to lag selection, and inclusion of variables. Although necessary diagnostic checking has been done, a robust analysis warrants a longer time series. The question remains inconclusive that if fiscal deficit does not cause significant crowding-out of private investment, then what are the channels of its negative influence on GDP.
\end{abstract}

Keywords: Fiscal Consolidation; Economic Growth; Cointegration; VECM.

\subsection{Introduction}

In the aftermath of the global economic slowdown, continued difficulties in the banking sector and a series of monsoon failure in many parts of the country have not yet liberated the Indian economy from decelerating growth and price rise. The latest steps like demonetisation and implementation of GST have led to added economic uncertainty in recent years. Essential commodities witness continual high prices. Growth rate remains below its potential.

\footnotetext{
*Corresponding author; Assistant Professor, Department of Economics, Ravenshaw University, Cuttack, Odisha, India. (Email id: chittaranjan.ru@gmail.com)

**Ph. D Research Scholar, Department of Economics, Ravenshaw University, Cuttack, Odisha, India. (Email id: manaswini48@gmail.com)
} 
Consequently, the policy options basically hover around balancing the trade-off between growth and inflation. Setting aside these, the government is also likely to go for a spending spree owing to implementation on the Seventh Pay Commission recommendations, One Rank One Pension (OROP), and flagship schemes like Skill India, Smart Cities, Swachh Bharat, etc. Moreover, the year before general elections often witnesses rise in public expenditure. The above observable facts lead to the apprehension of rise in public debt in near future. Rise in public debt, more often than not, has its implications on macroeconomic fundamentals like interest rate, prices and growth numbers. Therefore, the risks associated with possible build-up of unsustainable public finance, has brought back the issue of fiscal consolidation to the core of macroeconomic discourse.

Fiscal consolidation is basically a process of reducing fiscal deficiteither through raising revenue or reducing public expenditure or both. However, economists are not at one regarding the impact of fiscal consolidation on the economy. Generally speaking, there are three main schools of thought, viz. the Ricardian, the neoclassical, and the Keynesian approaches relating to the impact of fiscal consolidation. The Ricardian theory considers fiscal deficit as neutral in terms of its impact on growth. The argument gets a strong backing by Barro (1974), which postulates that for a given path of government expenditure, deficit finance reduces current tax, which leads to higher future taxes that have same percent value as in the initial cut. This in turn neither affects consumption nor investment, implies that the tax multiplier is zero in the long run.

The Keynesian view, on the other hand, argues that, when there are unemployed resources, autonomous increase in government expenditure, whether through investment or consumption, financed through borrowings causes output to expand through a multiplier process. As per this argument, fiscal consolidation through cut in expenditure directly reduces aggregate demand, while fiscal consolidation through increase in taxation dampen aggregate demand by reducing disposable income of the people.

The third leading school of thought is the neoclassical school of thought. As per this school, budget deficit may shift the tax burden to future generations and protect current aggregate demand. The neo-classical school of thought suggests that public spending only has a weak short run simulative impact on economic growth as it crowds out private expenditure Arestis and Sawyer (2004). So they prefer austerity measures to decrease public expenditure and increase the public saving rate instead, so that private investment and the market forces restore an equilibrium which leads stabilisation and recovery of the economy. 
Among the above three approaches, empirical support in favour of Ricardian equivalence is weak. The major competing theories are neoclassical and Keynesian approaches, where no stress is given on other aspects of fiscal consolidation like design, space, time, speed and so on. Also another fact found is that Keynes' ideas were widely accepted after World War II, and continue up to early 1970s. But after that in 1980 there was high fiscal imbalance in some major economies. So in 1990 a new school of economics emerged as a reform called Neo Keynesian economics, which dominated the main stream macroeconomic thought. It sought to unite the most realistic aspect of Keynes and neo classical assumptions and place them in more rigorous theoretical foundations than before. They argue for counter cyclical policies, i.e., raising taxes to cool the economy and to prevent inflation, when there is abundant demand side growth and engage in deficit financing to stimulate growth when there is economic down turn.

The debate on fiscal consolidation and its real effects has been unable to attain any culmination so far on analytical as well as empirical grounds. As far as empirical literature is concerned, some studies conclude that a successful fiscal consolidation is characterized by expenditure cut rather than tax increases (Giavazzi and Pagano, 1990; Alessina and Perotti, 1995, 1997; Mohanty, 1997; Mc Dermott and Wescott, 1996; Alberto and Ardagna, 1998). They suggest that a cut in expenditure should basically be cut in transfer payment and wage bill. On the contrary Hogan (2004), Rakhsit (2010), Delong and Summers (2012), Jan in t' Veld (2013), Sampawende and Tapsoba (2013), Guerson (2013), and Fatas and Summers (2016) state that deficit financing through fiscal consolidation measures led to positive effect on economic activity but their positive response is inefficient to offset the direct adverse effect of fiscal consolidation strategy on output and employment. Consolidation is more painful through tax enhancement.

There is also another view associated with tax-rise based fiscal consolidation as stated by Blanchard (1990) and Sutherland (1997). According to them if debt-GDP ratio is high, an increase in taxes shifts some of the tax burden from future to present generation and the increase in taxation reduces the government borrowing requirements, which leads to an induced wealth effect, leading to an increase in private consumption. On the other hand, reduction in borrowing requirements diminishes the risk premium associated with public debt issuance, which contributes to reduce real interest rate and allows crowding in private investment. Most of the above approaches are non-Keynesian in effect and supporting the neo classical school of thought.

However, studies on fiscal consolidation are available mostly for European Union and OECD countries. Emphasis has been basically on the holistic impact of fiscal consolidation on the growth and stability of an economy as a whole. Too little attempt is made relating to fiscal consolidation measures in India. Whatever literature is available, 
the focus mainly seems to be on the policies and programmes available for proper implementation of fiscal consolidation while little or no attention has been given on the fiscal consolidation measures that influence the growth and stability of an economy.

As far as Indian economy is concerned, during the first thirty years of independence, between 1950 and 1980, fiscal deficit was not so high. But in 1980 there was an adverse structural change in the government budget. Both revenue deficit and fiscal deficit persistently increased which in turn enhanced the burden of public debt and interest payment. The impact of India's large fiscal imbalances of the 1980s on the external sector resulting in the macroeconomic crisis in 1991 is massively documented, which necessitated a comprehensive reform programme whose major plank was fiscal consolidation. There was evidence of the successful fiscal correction during 1991-92 to 1996-97 (except for 1993-94) in terms of a significant reduction in the fiscal deficit through fiscal consolidation measures. However, the situation worsened during the East Asian Crisis of late 1990s

In an effort to renew the process of fiscal consolidation and provide for longterm macroeconomic stability, the Central government enacted the Fiscal Responsibility and Budget Management (FRBM) Act in August 2003. Both the Central and the State governments responsibly adhered to the legislation of bringing the fiscal deficit to 3 percent level of GDP by 2009. When the target was on the verge of attainment, the Global Economic Slowdown of 2007-08 destabilised the macroeconomic scenario altogether. Inflationary situation coupled with high interest rates subdued the growth rate. Blame was again shifted to the loose fiscal policy during 2008-11. Once again the focus of fiscal policy shifted to restore growth and stability through fiscal consolidation. The $13^{\text {th }}$ Finance Commission (TFC) revised the road map and targets to reduce fiscal deficit to 3 percent by 2013-14. The TFC also suggested for reducing the debt-GDP ratio to 68 per cent and eliminating revenue deficit completely. The revised road map was further revised, and finally the FRBM Act was amended to shift the 3 percent fiscal deficit target to be achieved by FY18-19. However, in the post-GST days in current FY 17-18, indirect tax revenue has witnessed significant reduction, which is a worrying factor from the view point of fiscal consolidation.

A study by Mundle, Bhanumurthy and Das (2011) through policy simulation model proves that it is possible to have fiscal consolidation while at the same time maintaining high GDP growth around 8 percent or so. The revised NIPFP macroeconomic policy simulation model has highlighted the roadmap of fiscal consolidation to achieve growth in real sector in aggregate sense and suggested for an expenditure switching policy of fiscal consolidation mechanism. As per this study, increasing government capital expenditure and reducing the government transfers could 
result in higher growth with a manageable fiscal deficit of 6 per cent that also brings down the government liability to its present level of 65 per cent (Bhanumurthy, et al. 2015).

While the mainstream macroeconomic policy seems to focus on fiscal consolidation, an important issue is raised by the heterodox school of thought against the orthodoxy in pegging the fiscal deficit number at 3 percent of GDP. They cite the Domar debt sustainability condition that as far as the growth rate of real GDP is higher than the real interest rate, debt should not be an issue especially when it is meant for capital expenditure. A review of the concerns of different schools of thought points to one core question, that does fiscal deficit reduce growth rate? If yes, by how much and in which ways? This paper attempts to close the research gap by examining the impact of fiscal consolidation on growth and other macroeconomic variables in India.

\subsection{Data and Methodology}

The present paper has used annual time series data for the period 1980-81 to 2013-14 collected from the Handbook of Indian Statistics published by Reserve Bank of India. The time period of the study is decided on the basis of data availability.

\subsection{Variables of the study}

a) Gross Domestic Product (GDP): GDP is considered to be a key variable which influences and is influenced by all other variables. The paper has taken $\mathrm{GDP}_{\mathrm{FC}}$ of India for all the years at current market prices as per base year 2004-05. An analysis of data at Current Market Prices is preferred because the fiscal numbers are stated in current prices.

b) Gross Fiscal Deficit (GFD): Fiscal deficit is the difference between total expenditure and total non-debt receipts of the government. The paper considers combined fiscal deficit of Centre and state governments, because macro variables in a federation like India are not just determined by the action of the Union government but also the action of the state governments.

c) Revenue Deficit $(R D)$ : This is the gap between revenue expenditure and revenue receipt. RD constitutes a major portion of fiscal deficit in India. However, of late many Indian states have substantially reduced their revenue deficit. An investigation on the relationship of RD with other variables is also a matter of interest.

d) Tax Revenue (TR): The paper considers tax revenues of both Centre and all states. It is expected that fiscal deficit may be corrected as a result of higher taxation. However, a higher tax rate is likely to have negative impact on GDP. 
e) Private Investment (PI): It is defined as the gross capital formation of private corporate sector. The impact of fiscal deficit on PI is always debated in literature. An examination of the relationship in Indian scenario is likely to provide some empirical insight to the mainstream schools of thought.

f) Capital Expenditure (CE): Capital expenditure is basically government expenditure on asset creation or liability reduction. Fiscal consolidation may provide some space of additional capital expenditure which in turn may help in raising GDP.

g) Social Sector Expenditure (SSE): When the government resorts to fiscal consolidation, it may be a case that consolidation is achieved by reducing expenditure on social sectors like education and health. The paper considers SSE of both Central and state governments for a time series analysis.

h) Interest Payment (INTP): Rise in fiscal deficit leads to higher interest payment, which may retard economic growth. However, in a country like India, where the major portion of the debt is internal, interest payments are simply a flow from the government to the private sector, which may again transmit to domestic saving. Impact of interest payment on GDP, therefore, needs empirical verification.

i) Call Money Rate (CMR): The present paper has considered Call Money Rate as a proxy variable for interest rate because this is the only one surrogate for which data are available for the study period.

j) Wholesale Price Index (WPI): WPI is the index from which inflation rate is measured. The paper has taken the weighted annual average WPI for the study period and converted them into one base year of 2004-05 by slicing. Fiscal consolidation can have either positive or negative impact on inflation, depending on its relative impact on aggregate demand and aggregate supply.

k) Exchange Rate $(R)$ : Foreign exchange rate is an indicator of a country's economic exchanges with rest of the world. If fiscal deficit raises interest rate, then international currencies flight into the country. As a result, foreign exchange rate declines means the domestic currency gets stronger. Impact may be insignificant if fiscal deficit does not affect interest rate. The present paper has taken the exchange rate of Indian rupee (INR) against US dollar as a proxy of foreign exchange rate, because dollar is a globally traded foreign exchange and US is a major trade partner of India.

\subsection{Log conversion}

Since the paper takes interest in analysing the variables in relative forms, all the variables in level form have been undergone logarithmic conversion. However, the variables in ratio scales are set aside from the log transformation process. It may be 
noted that the variable RD contained a few negative values. So its log transformation was not possible. To address the problem we added a constant to change the origin of the variable and did log conversion thereafter. After all such a procedure is not to have any impact on correlation and regression coefficients since log transformation is positive monotonic.

\subsection{Short listing of the variables}

Considering limited number of observations in the time series, the number of variables has also to be limited so that degrees of freedom for estimation are not lost unduly. Keeping this consideration, the paper has short-listed variables by observing zero order correlation coefficients. It may be noted that time series variables very often possess spurious correlation due to unit roots problem. Therefore, we have tested unit roots by applying Augmented Dickey Fuller test, and then examined the correlation matrix to shortlist the variables.

\subsection{The model}

Econometric literature proposes different methodological alternatives to empirically analyse the long-run relationships and dynamics interactions between two or more time-series variables. The most widely used methods include the full information maximum likelihood-based approach due to Johansen (1988) and Johansen and Juselius (1990). Since the present analysis involves a multivariate time series, the Jahansen method better fits to the data. After verifying unit roots and shortlisting the variables, we have tested existence of cointegration and applied the vector error correction model (VECM) with intercept. Considering all individual variables in the analysis are integrated of order 1, and the data generating process is k-dimensional VAR (p) process, then the VECM is as follows:

$$
\Delta y_{t}=\alpha \beta^{\prime} y_{t-1}+\sum_{i=1}^{p-1} \Gamma_{\mathrm{i}} \Delta y_{t-i}+v+u_{t}
$$

where the left hand side term is the vector of all endogenous variables in the model in first difference form. Since all are I (1) processes, $\Delta y_{t}$ is $\mathrm{I}(0)$. The rank of matrix $\Pi$ is called the cointegration rank or cointegrating rank of the processy $y_{t} . \Gamma_{i}$ is the coefficient matrix showing short run error correction. The term $v$ is the vector of constants(assuming constant trend), and $u_{t}$ is the disturbance term in the model. $\alpha$ and $\beta$ are both $r \mathrm{X} k$ matrices of rank $r<k$ (k being the number of parameters).

The model is called VECM because it explicitly includes the lagged error correction (EC) term $\Delta y_{t-1}$. The estimation has been followed by 


\subsection{Results and Discussion}

\subsection{A quick view of data}

Before estimation of the models, a quick look at data on Indian economy helps to have some basic view on the relationship between fiscal deficit and some key macroeconomic variables like growth rate, revenue deficit, tax receipts, private investment, interest rate, etc. It is noticeable that the combined fiscal deficit of the Centre and the states as a ratio of gross domestic product (GFDR) and growth rate of GDP (GR) are, more or less negatively associated (Figure 1). The negative relationship seems clear for the periods 1980s' and 2000s' but a bit sketchy for the periods 1990s' and post-2010.

Figure 1: Fiscal Deficit Ratio and Growth Rate of GDP $_{\mathrm{FC}}$.

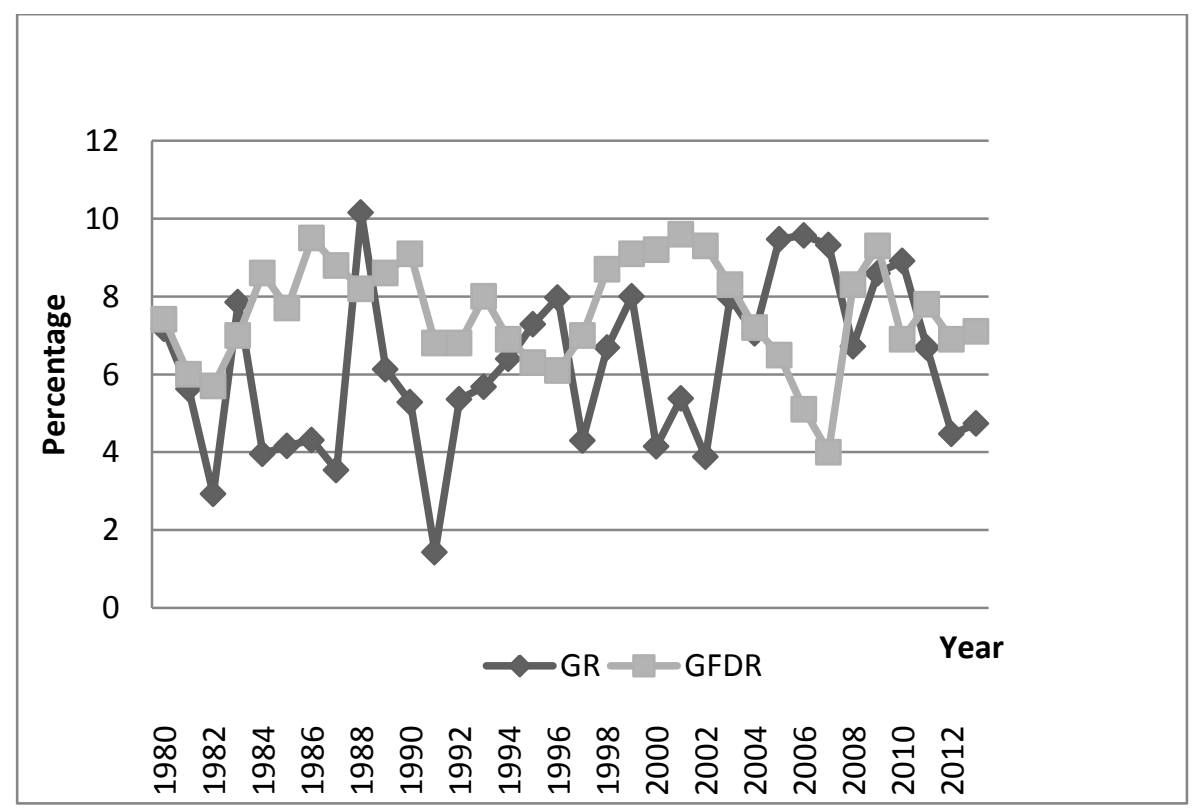

Source: Handbook of Statistics on Indian Economy, RBI.

However, the movement of fiscal deficit (FDR) and revenue deficit (RDR) follows the same time path (Figure 2). It is interesting to view that the gap between fiscal deficit and revenue deficit had widened in early 2000s', which gradually narrowed down subsequently. By 2008, combined FDR and combined RDR for the Centre and states were almost coinciding. Many Indian states were able to reduce their revenue as well as fiscal deficit as percent of GSDP. Deficit in the capital account had almost reduced to 
zero level in 2008. The FRBM target was about to be achieved by the Centre and some state governments. The matter worsened post 2008 as discussed in section 1.0.

Figure 2: Combined Fiscal Deficit and Revenue Deficit (percent of GDP)

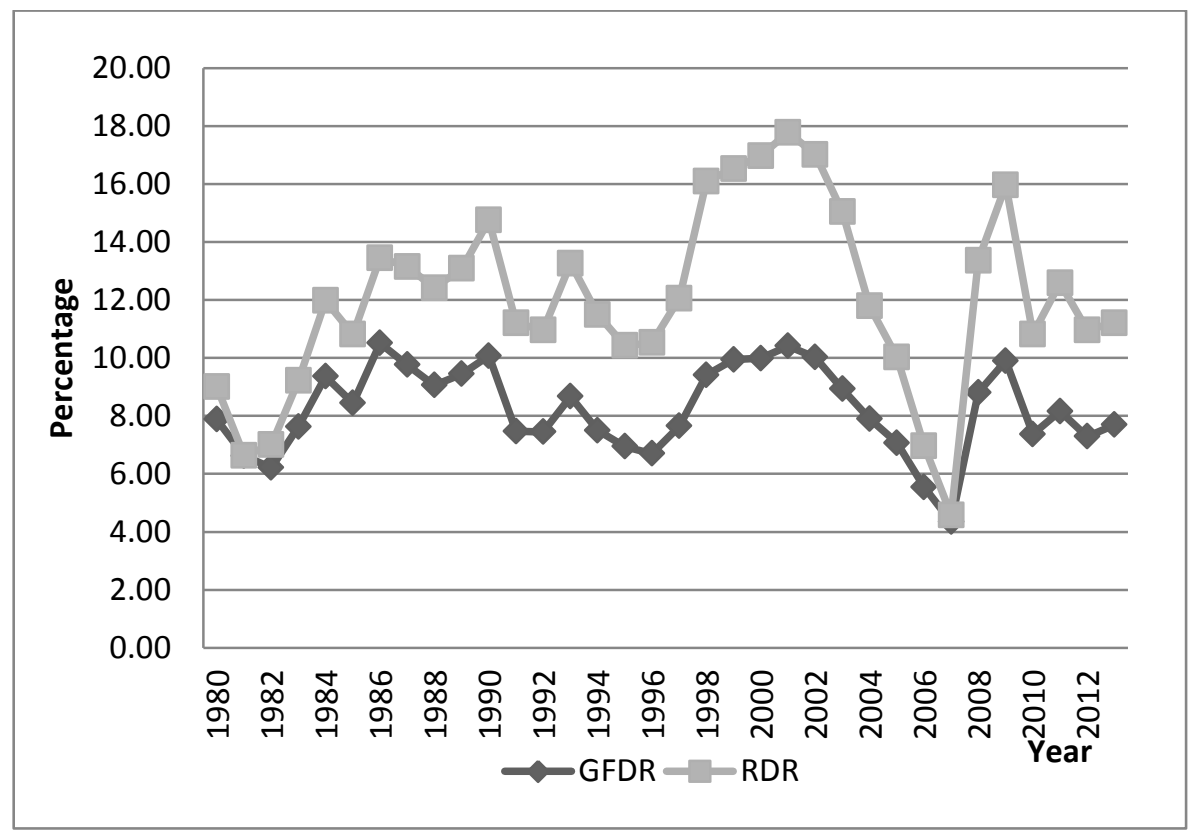

Source: Handbook of Statistics on Indian Economy, RBI.

Theoretically, fiscal deficit ratio should decline when tax revenue as a percent of GDP increases, and vice versa. But the evidence seems to be weak in India, except for the 2000s' (Figure 3). It is highly debated if fiscal deficit crowds-out private investment or not. A look at the macroeconomic data for the period 1980-2012, such a sign is apparent. A decline in fiscal deficit seems to be associated with rise in private investment (Figure 4). This is because of the fact that rise in fiscal deficit has not been associated with rise in capital expenditure in India. Figure 5 explains the phenomenon that gross capital expenditure of the Centre and all Indian states has almost stayed flat despite of fluctuations in fiscal deficit.

Then question arises that if fiscal deficit is not associated with capital expenditure, then does it affect interest rate? In the absence of any other time series data on interest rate for the study period, we have considered annual average call money rate 
as a proxy measure of interest rate. There is no clear evidence of any specific association between fiscal deficit-GDP ratio and the call money rate (Figure 6).

Figure3: Tax Revenue and Fiscal Deficit (percent of GDP)

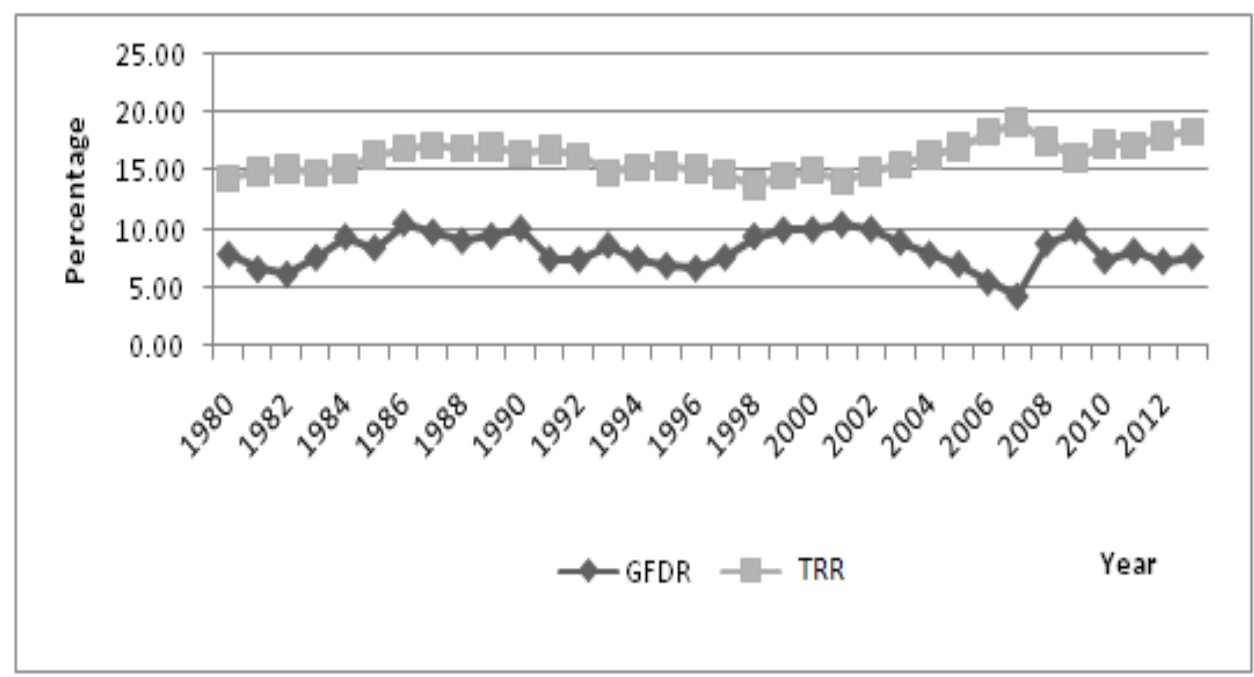

Source: Handbook of Statistics on Indian Economy, RBI

Figure 4: Fiscal Deficit and Private Investment (percent of GDP)

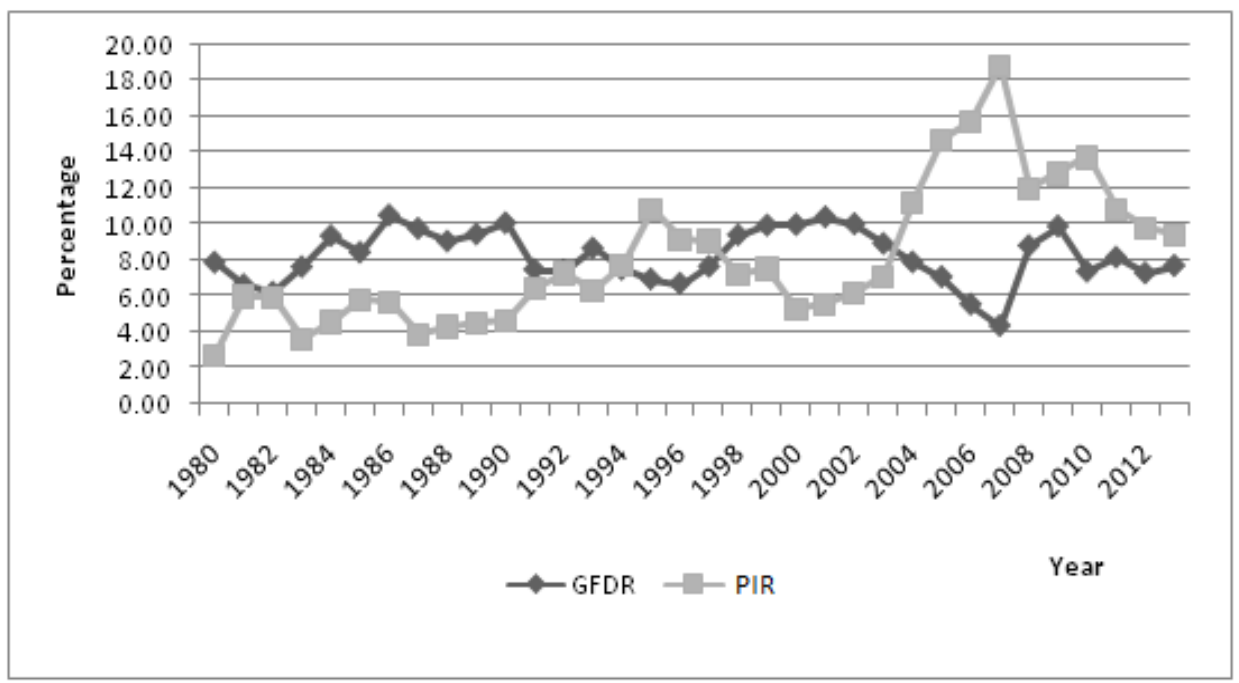

Source: Handbook of Statistics of Indian Economy, RBI. 
92 |VISION: Journal of Indian Taxation, Volume 4, Issue 2, Jul-Dec 2017

Figure 5: Fiscal Deficit and Capital Expenditure (percent of GDP)

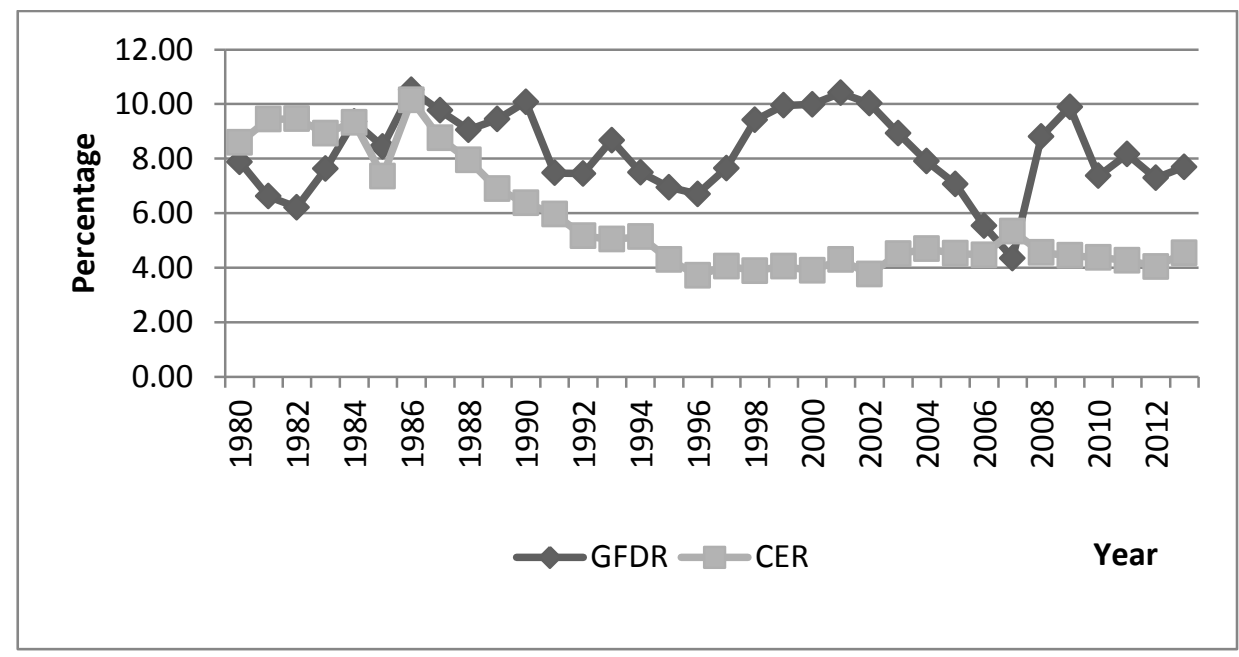

Source: Handbook of Statistics of Indian Economy, RBI.

Figure 6: Fiscal Deficit Ratio and Call Money Rate

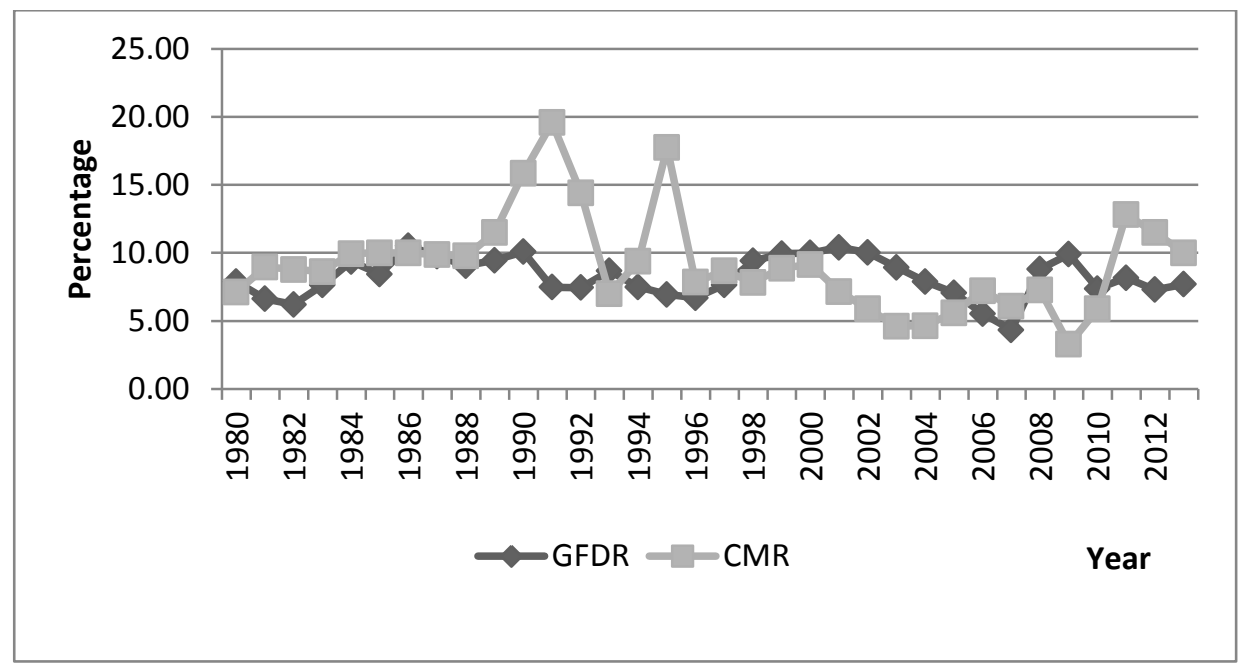

Source: Handbook of Statistics on Indian Economy, RBI.

The figures 1-6 give some impression of economic relationship between the selected variables. However, objective statements as such can be made only after an empirical assessment. 


\subsection{Unit roots test}

The paper uses Augmented Dickey Fuller Test to check if the time series contains unit roots and the results are presented in Table 1. The table shows that except for interest payment and call money rate, all other variables are stationary only at the first difference form. So they are I(1) processes.

Table 1: ADF Unit Root Test Results

\begin{tabular}{|c|c|c|c|c|c|}
\hline \multirow{2}{*}{$\begin{array}{c}\text { S. } \\
\text { No. }\end{array}$} & \multirow{2}{*}{ Variables } & \multicolumn{2}{|c|}{ Level } & \multicolumn{2}{c|}{ First Difference } \\
\cline { 3 - 6 } & & Test statistic & McKinnon p-value & $\begin{array}{c}\text { Test } \\
\text { statistic }\end{array}$ & $\begin{array}{c}\text { McKinnon } \\
\text { p-value }\end{array}$ \\
\hline 1 & $\ln$ & & -4.373 & 0.0003 \\
\hline 2 & $\operatorname{lnFD}$ & -0.631 & 0.9987 & -5.858 & 0.0000 \\
\hline 3 & $\operatorname{lnRD}$ & -2.075 & 0.2547 & -11.37 & 0.0000 \\
\hline 4 & $\ln$ TR & -0.220 & 0.9361 & -5.074 & 0.0000 \\
\hline 5 & $\ln \mathrm{PI}$ & -1.383 & 0.5903 & -6.24 & 0.0000 \\
\hline 6 & $\ln \mathrm{WPI}$ & -1.024 & 0.7445 & -5.796 & 0.0000 \\
\hline 7 & $\operatorname{lnCE}$ & 0.301 & 0.9774 & -9.089 & 0.0000 \\
\hline 8 & $\ln \mathrm{N}$ TP & -7.45 & 0.0000 & & \\
\hline 9 & $\ln$ SSE & -0.055 & 0.9537 & -5.723 & 0.0000 \\
\hline 10 & $\mathrm{CMR}$ & -3.056 & 0.0300 & & \\
\hline 11 & $\mathrm{R}$ & -0.165 & 0.9425 & -4.386 & 0.0003 \\
\hline
\end{tabular}

Source: Authors' computation by using STATA, lag=1, no intercept, no trend

\subsection{Correlation analysis}

After test of stationarity, we have made an analysis of the correlation matrix. As noted previously, the variables are log-transformed before unit roots test. The two variables LnINTP and CMR which are stationary at level form are retained in the level form and all other variables are transformed to first difference form (L1D1). Table 2 presents the zero order correlation matrix of all the variables. Except for CMR, which is in level form, all other variables are first differenced due to unit roots at level. Since the time series we have does not contain enough observations, retaining so many variables will reduce the degrees of freedom for the estimators. So we have eliminated some of them as follows. Out of fiscal variables FD, RD, TR and CE, we have taken only FD as it is the key variable to investigate in the present paper. FD also overlaps with variables like RD and TR. The correlation coefficients of CE with other variables seem to be insignificant $(<0.3)$. So CE is omitted for further analysis. Similarly, except for one or two cases, the variables like LnINTP and CMR, which are stationary at level form, are 
94 | VISION: Journal of Indian Taxation, Volume 4, Issue 2, Jul-Dec 2017

not showing any significant association with other variables in the matrix. LnSSE is dropped for collinearity problem due to data association with LnWPI. Thus we retain GDP, FD, PI, WPI and R for the final analysis.

Table 2: Correlation Coefficients

\begin{tabular}{|c|c|c|c|c|c|c|c|c|c|c|c|}
\hline - & $\begin{array}{c}\Delta \operatorname{lnGD} \\
\mathbf{P}\end{array}$ & $\begin{array}{c}\Delta \ln F \\
\mathbf{D}\end{array}$ & $\begin{array}{c}\Delta \ln R \\
D\end{array}$ & $\begin{array}{c}\Delta \ln T \\
\mathbf{R}\end{array}$ & $\begin{array}{c}\Delta \ln P \\
\mathbf{I}\end{array}$ & $\begin{array}{c}\Delta \mathbf{l n} \mathbf{W} \\
\text { PI }\end{array}$ & $\operatorname{lnCE}$ & $\begin{array}{c}\text { InIN } \\
\text { TP }\end{array}$ & $\begin{array}{c}\Delta \ln S \\
\text { SE }\end{array}$ & $\begin{array}{c}\mathbf{C M} \\
\mathbf{R}\end{array}$ & $\Delta \mathbf{R}$ \\
\hline $\begin{array}{c}\Delta \mathbf{l n G D} \\
\mathbf{P}\end{array}$ & 1.00 & & & & & & & & & & \\
\hline$\Delta \operatorname{InFD}$ & -0.07 & 1.00 & & & & & & & & & \\
\hline$\Delta \operatorname{lnRD}$ & -0.30 & 0.47 & 1.00 & & & & & & & & \\
\hline$\Delta \ln T R$ & 0.33 & -0.65 & -0.46 & 1.00 & & & & & & & \\
\hline$\Delta \ln P I$ & 0.11 & -0.55 & -0.58 & 0.50 & 1.00 & & & & & & \\
\hline $\begin{array}{c}\Delta \ln W P \\
\text { I }\end{array}$ & 0.12 & 0.41 & 0.10 & -0.001 & 0.01 & 1.00 & & & & & \\
\hline$\Delta \operatorname{lnCE}$ & 0.18 & -0.08 & $\begin{array}{l}-0.28 \\
\end{array}$ & 0.12 & 0.22 & 0.04 & 1.00 & & & & \\
\hline $\operatorname{lnINTP}$ & 0.36 & -0.05 & -0.03 & -0.06 & -0.16 & -0.16 & 0.07 & 1.00 & & & \\
\hline$\Delta \operatorname{lnSSE}$ & 0.18 & 0.43 & 0.13 & -0.02 & -0.05 & 0.98 & 0.02 & 0.01 & 1.00 & & \\
\hline CMR & -0.44 & -0.07 & 0.01 & 0.09 & 0.09 & -0.32 & -0.29 & -0.31 & -0.34 & 1.00 & \\
\hline$\Delta \mathbf{R}$ & -0.40 & 0.28 & 0.17 & -0.52 & -0.26 & -0.23 & -0.32 & 0.07 & 0.05 & 0.31 & 1.00 \\
\hline
\end{tabular}

Source: Authors' computation by using STATA

\subsection{Lag selection}

Time series analysis very often becomes sensitive to lag selection. Therefore, we have applied various objective criteria of lag selection. Most of the criteria suggest for lag 4 as the optimal lag for our analysis (Table 3). Only SBIC suggests for lag 1. Although decision is usually taken in favour of the majority, here we prefer to become judgmental on the ground that it is an annual time series data, and the number of observations is not high. Selecting more lags will defeat the purpose of elimination of some less relevant variables. Therefore, we prefer to go by the SBIC, and lag 1 is selected as the optimal lag.

Table 3: Lag Selection

\begin{tabular}{|c|c|c|c|c|c|c|}
\hline Lags & LL & LR & FPE & AIC & HQIC & SBIC \\
\hline 0 & 7.7572 & & $5.7 \mathrm{e}-07$ & -.183814 & -.109104 & .049719 \\
\hline 1 & 171.16 & 326.8 & $5.8 \mathrm{e}-11$ & -9.41064 & -8.96239 & $-8.00945^{*}$ \\
\hline 2 & 188.62 & 34.921 & $1.1 \mathrm{e}-10$ & -8.908 & -8.0862 & -6.33914 \\
\hline 3 & 227.794 & 78.348 & $6.7 \mathrm{e}-11$ & -9.85295 & -8.6576 & -6.11642 \\
\hline 4 & 286.772 & $117.96^{*}$ & $2.0 \mathrm{e}-11^{*}$ & $-12.1181^{*}$ & $-10.5493^{*}$ & -7.21395 \\
\hline
\end{tabular}

Source: Authors' computation by STATA 


\subsection{Johansen test for cointegration}

Since all the five variables are integrated of the same order, i.e. I(1), there is a possibility of existence of cointegration among them, which would suggests existence of long run association among the variables. The results of the Johansen Cointegration test are presented in Table 4. As per this test, decision on number of cointegrating vectors is made either on the basis of the trace statistics and/or the Maximum Eigen value. When trace/Max statistics is higher than the 5\% critical value, the null is rejected. The present paper has applied both the criteria, and the Null, that no cointegrating equation exists, is rejected. Both the tests suggest for acceptance of the alternative hypothesis that at most one cointegrating equation exists. It may be noted that the number of cointegrating equations as per Johansen test is sensitive to lag selection. As already reported in section 3.4 , as per SBIC we have selected lag 1. Still for robustness of this conclusion, we tried for cointegrating equation by taking lag 2 , and the test also confirms existence of "at most 1 " cointegrating equation.

Table 4: Johansen Co-integration Test Results

\begin{tabular}{|c|c|c|c|c|c|}
\hline $\begin{array}{c}\text { Lag } \\
\text { Order }\end{array}$ & $\begin{array}{c}\text { Hypothesised No } \\
\text { of C-Equations }\end{array}$ & $\begin{array}{c}\text { Trace } \\
\text { Stats }\end{array}$ & $\begin{array}{c}\mathbf{5 \%} \text { critical } \\
\text { value }\end{array}$ & $\begin{array}{c}\text { Max Eigen } \\
\text { value }\end{array}$ & 5\% critical value \\
\hline 1 & None & 71.50 & 68.52 & 37.62 & 33.46 \\
\hline & At most 1 & $33.68^{*}$ & 47.21 & $19.74 *$ & 27.07 \\
\hline & At most 2 & 13.94 & 29.68 & 9.95 & 20.97 \\
\hline & At most 3 & 3.99 & 15.41 & 3.26 & 14.07 \\
\hline & At most 4 & 0.73 & 3.76 & 0.73 & 3.76 \\
\hline 2 & At most 0 & 74.50 & 68.52 & 34.82 & 33.46 \\
\hline & At most 1 & $39.68^{*}$ & 47.21 & $22.13^{*}$ & 27.07 \\
\hline & At most 2 & 17.55 & 29.68 & 14.47 & 20.97 \\
\hline & At most 3 & 3.08 & 15.41 & 2.71 & 14.07 \\
\hline & At most 4 & 0.37 & 3.76 & 0.37 & 3.76 \\
\hline
\end{tabular}

Source: Authors' computation

Note: VEC rank lnGDP $\operatorname{lnFD} \operatorname{lnPI} \operatorname{lnWPI}$, R, trend(constant) lags(1) and lag(2)max,

Number of obs $=33$, For lag(2), no. of obs $=32$.

*indicates that there exists one cointegrating vector of the chosen variables.

\subsection{Estimation of VECM}

Apart from the long-run equilibrium relationship, one often cares about the associated short-run fluctuations. VEC model is applied for this purpose. VEC captures the rich dynamic relationships among the variables that may provide valuable insights on 
policy analysis based on dynamic responses of non-policy variables due to unexpected shocks in policy variables.

The equation of our model is

$$
\Delta y_{t}=\alpha \beta^{\prime} y_{t-1}+\sum_{i=1}^{p-1} \Gamma_{\mathrm{i}} \Delta y_{t-i}+v+u_{t}
$$

where $y_{t}$ is the vector of variables (all are treated as endogenous in our model). Since we have a $\operatorname{VAR}(1)$ process, the equation reduces to

$$
\Delta y_{t}=\alpha \beta^{\prime} y_{t-1}+\Gamma \Delta y_{t-1}+v+u_{t}
$$

The results of our estimation are presented below.

$$
\begin{aligned}
& \hat{\alpha}=\left(\begin{array}{lllll}
-0.172 * * & -0.885 & 0.891 & 0.034 & -3.814
\end{array}\right), \\
& \hat{\beta}=\left(\begin{array}{lllll}
1 & 0.224 & -0.141-0.0549 & -0.001
\end{array}\right) \\
& \hat{v}=\left(\begin{array}{lllll}
-0.078 & -0.468 & 0.729 & 0.031 & 0.283
\end{array}\right)
\end{aligned}
$$

$$
\text { and } \Gamma=\left(\begin{array}{ccccc}
0.115 & -0.005 & -0.021 & -0.137 & 0.0004 \\
-1.289 & -0.351 & -0.0304 * & 7.576 & -0.012 \\
1.836 & 0.241 & 0.181 & -4.767 & 0.005 \\
0.161 & -0.005 & -0.001 & -0.001 & -0.0001 \\
-23.68 & 5.086 & -0.195 & -68.79 & -0.035
\end{array}\right)
$$

It may be noted here that the vector $y_{t}$ in our study is defined as

$$
y_{t}=(\operatorname{LnGDP} \operatorname{LnFD} \text { LnPI LnWPI R) }
$$

The vector $\alpha$ specifies the vector of speed of adjustment indicating error correction. In our estimation there is at most one cointegrating equation, i.e. for LnGDP as -0.172 is significant at 1 percent level. It is of negative sign, which means GDP comes back to its equilibrium at a rate of 17.2 percent in a year after getting any kind of shock in the right hand variables. As regards, exchange rate $(R)$ the sign is also negative but not significant. For other kind of variables, there is no steady state achievement due to shocks of any kind in the variables of the study. The short run error correction are stated in matrix $\Gamma$, in which only one coefficient, i.e. of private investment to fiscal deficit is significant. This means when private investment increases by one percent fiscal deficit gets corrected by about 3 percent in a year, and this is significant. This is possible since rise in private investment raises GDP as well as revenue of the government. The need for government investment (capital expenditure) may recede, there by some fiscal consolidation may be possible.

In the VECM, $\beta$ is the long run parameter vector. Since we have one cointegrating vector in the model, there is only one $\beta$-vector to be analysed. The details of estimated $\beta$ are presented in Table 5. It may be noted that $\beta$ vector is exactly 
identified, and Johansen normalisation restriction, all the $\beta$-coefficients except for $\mathrm{R}$ are significant. Putting it more specifically, the long-run relationship between LnGDP and the right hand side variables is as follows:

$$
\begin{aligned}
& \operatorname{LnGDP} P_{t}=-0.224 \operatorname{LnFD}_{t}, \text { (significant) } \\
& \operatorname{LnGDP} P_{t}=0.141 \operatorname{LnPI}_{t}, \text { (significant) } \\
& \operatorname{LnGDP} P_{t}=0.0549 \operatorname{LnWPI}_{t}, \text { (significant) } \\
& \text { and } L n G D P_{t}=0.001 R_{t} . \text { (NOT significant). }
\end{aligned}
$$

Therefore, the paper finds that one percent rise in fiscal deficit reduces GDP by 0.22 percent, which is significant. But one percent rise in private investment increases GDP by 0.141 percent, and one percent increase in price index (WPI) raises GDP by 0.055 percent. These are significant (Table 5).

Table 5: Estimation of $\beta$ and $\alpha$ Vectors

\begin{tabular}{|l|l|l|l|l|l|l|l|l|}
\hline \multirow{2}{*}{} & \multirow{2}{*}{ Variable } & \multicolumn{3}{|l|}{$\beta$ (long run parms) estimation } & \multicolumn{4}{|l|}{$\alpha$ (adjustment coefficient) estimation } \\
\cline { 3 - 9 } & & Coefficient & $\mathrm{Z}$ & $\mathrm{p}>|\mathrm{z}|$ & Variable & Coefficient & $\mathrm{Z}$ & $\mathrm{p}>|\mathrm{z}|$ \\
\hline Ce_1 & LnGDP & 1 & & & $\Delta$ LnGDP & -0.172 & -2.62 & 0.009 \\
\cline { 2 - 9 } & LnFD & .2242 & 2.13 & 0.033 & $\Delta$ LnFD & -0.885 & -1.51 & 0.132 \\
\cline { 2 - 9 } & LnPI & -.1413 & -3.66 & 0.000 & $\Delta$ LnPI & 0.891 & 1.11 & 0.265 \\
\cline { 2 - 9 } & LnWPI & -.0549 & -4.59 & 0.000 & $\Delta \ln$ WPI & 0.034 & 1.08 & 0.279 \\
\hline \multirow{3}{*}{} & $\mathrm{R}$ & -.0011 & -0.36 & 0.718 & $\Delta \mathrm{R}$ & -3.814 & -0.47 & 0.64 \\
\cline { 2 - 9 } & \multirow{2}{*}{ cons } & -3.0652 & & & & & & \\
\hline
\end{tabular}

Source: Authors' estimation by using STATA.

Note: Johansen normalization restriction imposed

The $\chi$-square value of the cointegrating equation 1 is 4365.37 , which is statistically significant ( $\mathrm{p}$-value=0.000). The VECM for all the five equations are presented in Table 6. Although the overall regressions of all the equations are significant, only GDP shows a long term relationship with the other variables because $\alpha$, the adjustment coefficient, is significant for the equation when LnGDP is the left hand side variable (Table 6).

Table 6: VECM of all the Equations

\begin{tabular}{|c|c|c|c|}
\hline $\begin{array}{c}\text { Equation } \\
\text { (LHS variable) }\end{array}$ & $\boldsymbol{R}^{\mathbf{2}}$ & $\boldsymbol{\chi}^{\mathbf{2}}$ & p-value \\
\hline$\Delta$ LnGDP & 0.922 & 296.22 & 0.0000 \\
\hline$\Delta$ LnFD & 0.545 & 29.907 & 0.0001 \\
\hline$\Delta$ LnPI & 0.33 & 14.859 & 0.0375 \\
\hline$\Delta$ LnWPI & 0.696 & 57.149 & 0.0000 \\
\hline$\Delta \mathrm{R}$ & 0.417 & 17.889 & 0.0125 \\
\hline
\end{tabular}

Sample 1982-2013, $N=32, L L=172.99$ 


\subsection{Diagnostic checks}

The results of VECM may be erroneous if the data generating process witness problems of autocorrelation and other such problems. The paper, therefore, hasmade diagnostic checks of autocorrelation, normality and stability of the model. The Lagrange multiplier test is used in order to detect if serial correlation is present or not. The null hypothesis that there is no autocorrelation stands valid (Table 7). Similarly, the JarqueBera test that variables are normally distributed also stands valid (Table 8).

Table 7: Lagrange Multiplier Test

\begin{tabular}{|c|c|c|}
\hline Lag & Chi-square & Prob>chi2 \\
\hline 1 & 18.6883 & 0.81182 \\
\hline 2 & 29.9860 & 0.2926 \\
\hline 3 & 27.6902 & 0.32231 \\
\hline
\end{tabular}

H0: no autocorrelation at lag order

Table 8: Jarque-Bera Test for Normality

\begin{tabular}{|l|c|c|}
\hline Equation & Chi-square & Prob>chi2 \\
\hline$\Delta$ LNGDP & 1.608 & 0.44763 \\
\hline$\Delta$ LNFD & 0.721 & 0.69748 \\
\hline$\Delta$ LNPVTIN & 1.513 & 0.46919 \\
\hline$\Delta$ LNWPI & 0.552 & 0.75869 \\
\hline$\Delta$ R & 0.431 & 0.80615 \\
\hline All & 4.825 & 0.90256 \\
\hline
\end{tabular}

H0: Variables are normally distributed

Figure 7: Roots of the companion matrix

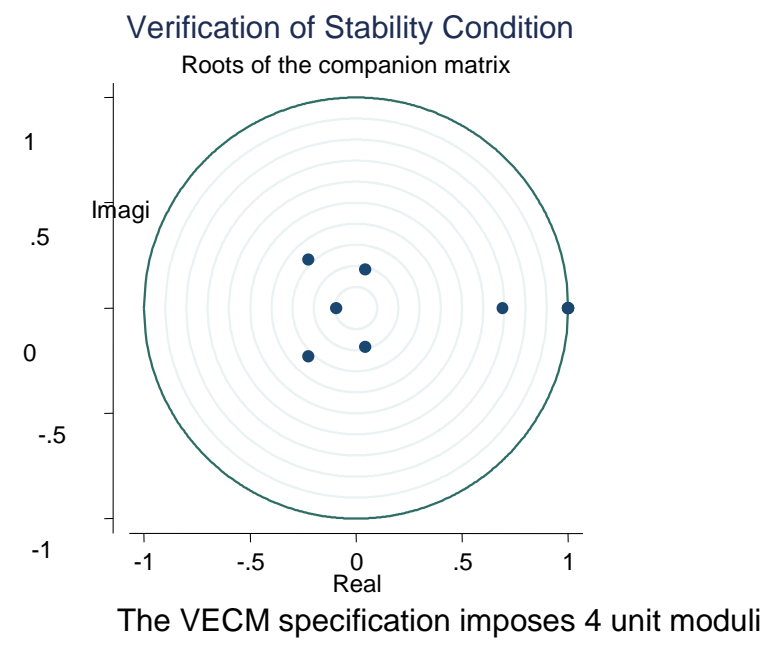


The stability of the VECM is tested by using the Roots of the companion matrix. The VECM specification imposes four units moduli. But the other moduli are not closer to unit. So the model does not violate the stability condition (Figure 7).

\subsection{Summary and Conclusion}

The paper attempts to examine whether fiscal consolidation has any impact on economic growth. Since the impact of fiscal consolidation transmits to GDP through some channels, the paper shortlisted a few such channels like WPI, private investment(PI), and exchange rate $(\mathrm{R})$ to examine the relationship between fiscal deficit and economic growth. By application of Johansen cointegration method, the paper observes that fiscal deficit has negative impact on economic growth. However, the questions like whether or not fiscal deficit is inflationary(?), and does it crowd-out private investment (?) could not be established by the present paper.

The paper, however, can conclude that there exists a long-run relationship between GDP and fiscal consolidation, inflation and private investment. GDP increases due to occurrence of these phenomena. However, the conclusions as such are sensitive to lag selection, and variable selection. Although necessary diagnostic checking has been done, analysis as such warrants a longer time series for robust results.

\section{References}

Alberto, A., \& Ardagna, S. (1998). Tales of fiscal adjustment. Economic Policy, 13(27), 488-545.

Alessina, A., \& Perotti, R. (1995). The political economy of budget deficit . International Monetary Fund Staff Papers, 42(1), 1-31.

Alesina, A., \& Perotti, R. (1997). Fiscal adjustment in OECD countries: composition and macroeconomic effects. IMF Staff Papers, 44(2), 210-248.

Arestis, P., \& Sawyer, M. (2004). Fiscal Policy: A potent instrument. New School Economic Review, 1(1), 15-21.

Barro, R. (1974). Are government bonds net wealth? Journal of Political Econom, 82(6), 1095-1117. 
Bhanumurthy, N.R., Bose, S. \& Chakravartti, P. (2015). Targeting debt and deficits in India: A structural macroeconometric approach. Working Paper No.148, NIPFP, New Delhi

Blanchard, O. (1990). Comment. In O. J. Blanchard \& S. Fischer (Eds), NBER Macroeconomics Annual, 5, pp.111-116. Massachusetts: MIT Press

Delong, B.J., \& Summers, H.L. (2012). Fiscal policy in a depressed economy. Brooking Papers on Economic Activity, Spring, 233-297.

Fatas, A., \& Summers, L. H. (2016). The permanent effects of fiscal consolidations. (Working Paper No. 22374). Retrieved from National Bureau of Economic Research website: http://www.nber.org/papers/w22374.pdf

Giavazzi, F., \& Pagano, M. (1990). Can severe fiscal contractions be expansionary? Tales of two small european countries. In O. J. Blanchard \& S. Fischer (Eds), NBER Macroeconomics Annual, 5, pp.75-122. Massachusetts :MIT Press

Guerson, A. (2013). The composition of fiscal consolidation matters: Policy simulations for Hungary. IMF Working Paper/13/207. Fiscal Affairs Department. Retrieved from https://www.imf.org/external/pubs/ft/wp/2013/wp13207.pdf

Hogan, V. (2004). Expansionary fiscal contractions? Evidence from panel data. The Scandinavian Journal of Economics, 106(4), 647-659.

Jan in t' Veld. (2013). Fiscal consolidations and spillovers in the Euro area periphery and core. European Economy, Economic Papers 506. Retrieved from http://ec.europa.eu/economy_finance/publications/economic_paper/2013/pdf/ecp506_en. pdf

Johansen, S. (1988). Statistical analysis of co integration vectors. Journal of Economic Dynamics and Control, 12(2-3), 231-254.

Johansen, S., \& Juselius, K. (1990). Maximum likelihood estimation and inference on co integration- with applications to the demand for money. OXFORD Bulletin of Economics and Statistics, 52(2), 0305-9049. 
Mc Dermott, J. \& Wescott, C R. (1996). An emprical analysis of fiscal adjustment. IMF Staff Papers, 43(4), 725-753.

Mohanty, M. S. (1997). Macro-economic stability, growth and fiscal reform: The Indian perspective. Economic and Political Weekly, 32(6), 289-298.

Mundle, S., Bhanumurthy, N.R., \& Das, S. (2011). Fiscal consolidation with high growth: A policy simulation model for India. Economic Modelling, 28(6), 2657-2668.

Rakhsit, M. (2010). Fiscal consolidation and inclusive growth: Thefinance commission approach. Economic and Political Weekly, 45(48), 56-63.

Report of the Thirteenth Finance Commission. (2009). Retrived from http://www.fincomindia.nic.in.

Sampawende, J. \& Tapsoba, A. (2013). Options and strategies for fiscal consolidation in India. Economic Modelling, Elsevier, 43(C), 225-237.

Sutherland, A. (1997). Fiscal crises and aggregate demand: Can high public debt reverse the effects of fiscal policy? Journal of Public Economics, 65(2), 147-162. 